\title{
SYNOWIE HAGAR. WIEDZA BIZANTYŃCZYKÓW O ARMII ARABSKIEJ W ŚWIETLE TRAKTATÓW WOJSKOWYCH Z IX I X WIEKU**
}

Ekspansja arabska okazała się poważnym wyzwaniem dla Bizantyńczyków na polu militarnym ${ }^{1}$. Arabowie, zwani w źródłach bizantyńskich Agarenami (czyli potomkami biblijnej Hagar) ${ }^{2}$, lub Saracenami ${ }^{3}$, począwszy od VII w. zadali cesarstwu ciężkie ciosy. Utrata ważnych wschodnich prowincji, a następnie konieczność obrony Azji Mniejszej, wysp na Morzu Sródziemnym, wreszcie samej stolicy przed armią muzułmańską, wymogły dostosowanie zasad prowadzenia wojny do nowych wyzwań. By to uczynić, konieczne było poznanie metod walki przeciwnika i organizacji jego oddziałów. Wiedzę tę Bizantyńczycy pozyskiwali w pierwszym rzędzie $\mathrm{z}$ bezpośredniej praktyki - uczestnicząc w odpieraniu arabskich najazdów czy podejmując próby

* Dr hab. Teresa Wolińska, prof. UŁ - profesor nadzwyczajny w Katedrze Historii Bizancjum Uniwersytetu Łódzkiego w Instytucie Historii na Wydziale Filozoficzno-Historycznym; e-mail: t.wolinska@wp.pl.

** Niniejszy artykuł powstał w ramach grantu NCN (projekt 2012/04/M/HS3/00564: Bizancjum i Arabowie. Spotkanie cywilizacji VI-VIII w.).

${ }^{1} \mathrm{Z}$ nową religią przyszło się Bizantyńczykom zmierzyć także na polu ideologicznym. Ta kwestia wykracza jednak poza ramy niniejszego tekstu. Szerzej zajęłam się nią w innym artykule: Elity chrześcijańskie wobec islamu (VII-X w.), który ukaże się w VoxP 35 (2015) t. 64.

${ }^{2}$ Por. Anonymus Byzantinus, De re strategica 21 i 32, ed. G.T. Dennis: Anonymous Book of Tactics, w: Three Byzantine Military Treatises, text, translation and notes by G.T. Dennis, Dumbarton Oaks Texts 9, CFHB (Series Washingtonensis) 25, Washington 1985, 302-304 i 327; Nicephorus II Phokas, De velitatione bellica 15, ed. G.T. Dennis: Skirmishing, w: Three Byzantine Military Treatises, s. 198 (dzieło przypisywane było Niceforowi II Fokasowi, obecnie uważane jest jednak za traktat, którego autorstwo trudno stwierdzić; dalej cytuję więc sam tytuł De velitatione bellica). Na temat nazewnictwa Arabów, por. A.G.C. Savvides, Some notes on the Term Agarenō̄, Ismaelìtai and Sarakenō̄ in Byzantine Sources, „Byzantion” 67 (1997) 89-96. Zdarza się też, że kronikarze używają nazw Arabes i Agarenoi. Czyni tak np. Leon Diakon (Historiae libri decem II 1, rec. C.B. Hase, CSHB 3, Bonnae 1828, 17, 9 i 18, 7).

${ }^{3}$ Por. Leo VI Sapiens, Tactica passim, ed. i thum. w: The Taktika of Leo VI, text, translation, and commentary by G. Dennis, Dumbarton Oaks Texts 12, CFHB (Series Washingtonensis) 49, Washington 2010, passim. Pochodzenie terminu Saraceni nie jest pewne, chociaż później łączono go z imieniem Sara. Szerzej na ten temat, por. М.Д. Бухарин, Произхождение этнонима Баракұvoí, „Византийский Временник” 67(92) (2008) 57-62. 
odzyskania utraconych pozycji. Pomocą mogli im służyć w tym zakresie najemnicy arabscy służący w szeregach armii bizantyńskiej, np. jeźdźcy pochodzący z beduińskiego plemienia Banu Habib, rywale Hamdanidów, którzy znaleźli się pod komendą bizantyńską w czasach Romana Lekapena (ok. 870 15 VI 948; cesarz w latach 920-944)4. Beduini, określani w źródłach bizantyńskich nazwą Arabitai w odróżnieniu od Arabów, wykorzystywani byli przede wszystkim jako zwiadowcy i harcownicy. Byli oni z pewnością cennym źródłem informacji o swych pobratymcach, podobnie jak inni Arabowie służący cesarstwu, np. eunuch Samonas 5 .

Równocześnie trzeba pamiętać, że długotrwałe sąsiedztwo Bizancjum najpierw z plemionami arabskimi, a potem $\mathrm{z}$ kalifatem, nie ograniczało się wyłącznie do zmagań militarnych. Towarzyszyła im, bardziej lub mniej świadoma, wymiana kulturowa. Wskutek tego do bizantyńskiej polemologii przenikały elementy arabskiej sztuki wojennej. Z drugiej strony wielu Bizantyńczyków z różnych powodów podejmowało służbę w armii i flocie arabskiej. Wystarczy wspomnieć słynnego Leona z Trypolisu (floruit: 2. poł. IX - 1. poł. $\mathrm{X}$ w.), odpowiedzialnego $\mathrm{z}$ atak na Tesalonikę w roku $904^{6}$, czy innego Greka w służbie arabskiej, Damiana Ghulam Yazamana ( $†$ ok. 915) ${ }^{7}$. Oni z kolei byli dla muzułmanów źródłem informacji na temat wojskowych sił cesarstwa.

Wzrost zagrożenia arabskiego, także w zachodnich posiadłościach cesarstwa, przypadł na okres rządów Leona VI Filozofa (19 IX 866 - 11 V 912; cesarz od 29 VIII 886). Pochodzący z dynastii macedońskiej cesarz wstapił na tron po swym ojcu Bazylim I (ok. 811 - 29 VIII 886; cesarz od 23 IX 867) ${ }^{8}$. Do 904 r. panował wspólnie z bratem Aleksandrem (ok. 870 - 6 VI 913; cesarz od 11 V 912), następnie samodzielnie do śmierci w roku 912. Mimo, iż jego ojciec był wyróżniającą się postacią wśród władców Bizancjum, Leon zastał siły zbrojne, szczególnie flotę, w nienajlepszym stanie, co skutkowało szeregiem klęsk, ponoszonych z rąk sąsiadów ${ }^{9}$. To właśnie za jego rządów w ręce muzuł-

${ }^{4}$ Por. S. Tougher, The Reign of Leo VI (886-912). Politics and People, Leiden - New York 1997, 212-216.

${ }^{5} \mathrm{~W} 904$ r. podjął próbę ucieczki do swoich ziomków. Jej powody są przedmiotem sporów uczonych, por. R. Jenkins, The Flight of Samonas, „Speculum” 23 (1948) nr 2, 217-235; R. Janin, Un Arabe ministre a Byzance: Samonas, EO 34 (1935) 307-318.

${ }^{6}$ Por. R. Khoury Odetallah, Leo Tripolites - Ghulam Zurafa and the Sack of Thessaloniki in 904, „Byzantinoslavica” 54 (1995) nr 1, 97-102.

${ }^{7}$ Damian walczył z Tulunidami w Egipcie - dowodził flotą (prawdopodobnie Tyru), która wpłynęła do delty Nilu, por. W.A. Farag, Some Remarks on Leo of Trypolis'Attack on Thessaloniki in 904 A.D., ByZ 82 (1989) 137; Khoury Odetallah, Leo Tripolites, s. 98.

${ }^{8}$ Od 870 r. był współwładcą u boku ojca, Bazylego I. Jego matką była Eudokia Ingerina (kochanka cesarza Michała III Metystesa (19 I 840 - 23/24 IX 867; cesarz od 20 I 842), stąd niektórzy historycy to jemu przypisują ojcostwo). Panowanie rozpoczął od usunięcia z patriarchatu Focjusza i mianowania na jego miejsce swego brata Stefana.

${ }^{9}$ Por. Tougher, The Reign of Leo VI, s. 184. Pierwszy rajd morski miał miejsce w 888 r. Dziesięć lat później poważnych zniszczeń dokonał eunuch Ragib: wziął 3 tys. jeńców, spalił wiele statków 
manów wpadła Taormina (902), ostatni przyczółek Bizantyńczyków na Sycylii $^{10}$. Wzrosło zagrożenie Tesalii i Peloponezu. W 904 r. Arabowie zaatakowali i zdobyli Tesalonikę ${ }^{11}$. Wbrew opiniom części badaczy, którzy uważają Leona VI za słabego władcę i kiepskiego dowódcę ${ }^{12}$, podkreślić trzeba, że cesarz nie pozostał obojętny wobec tych wydarzeń. Sam nie był wojownikiem i nie miał

bizantyńskich, zajął kilka twierdz, por. A.A. Vasiliev, Byzance et les Arabes, t. 2/1: La Dynastie Macédonienne (867-959), trad. M. Canard, Bruxelles 1968, 133. W latach 891-892 ofiarą ataku padła Samos.

${ }^{10}$ Miasto zostało zdobyte 1 sierpnia 902, por. 'An Nuwayri, Dal Nibayat 'al 'arib, trad. da M. Amari: Il sommo sforzo di chi conosce le varie parti dell'erudizione, w: Bibliotheca arabo-sicula: versione italiana, raccolta da M. Amari, vol. 1, Torini - Roma 1880 (reprint: Frankfurt am Main 1994), 151; Romoaldus, Annales a. 893-1178, ed. W. Arndt, MGH Scriptores 19, Hannoverae 1866, 398, 37; Ibn al-Athir, Kitāb al-Kāmil al-Tawārīkh, trad. da M. Amari: Cronaca compiuta, w: Bibliotheca arabo-sicula, vol. 1, s. 394; Ibn-Khaldûn, Kîtâb el-'Iber, trad. da M. Amari: Libro dei concetti storici, w: Biblioteca arabo-sicula, vol. 1, s. 169; Georgius Monachus, Vitae imperatorum recentiorum, rec. I. Bekker, CSHB 31, Bonnae 1838, 860-861; Joannes Scylitzes, Synopsis historiarum, rec. I. Thurn, CFHB (Series Berolinensis) 5, Berolini 1973, 181 i 183; Leo Grammaticus, Chronographia, rec. I. Bekker, CSHB 42, Bonnae 1842, 274-275; Theodosius Melitenus, Chronographia, ed. Th.L.F. Tafel, Monumenta Saecularia 3/1, Monachii 1859, 192; Joannes Diaconus, Translatio sancti Severini 2, ed. G. Waitz, MGH Scriptores Rerum Langobardicarum et Italicarum saec. VI-IX, Hannoverae 1878, 453, 46 - 454, 17; Constantinus Porphyrogemitus Imperator, De thematibus, ed. A. Pertusi: Costantino Porfirogenito, De thematibus, introduzione, testo critico, commento a cura di A. Pertusi, Studii e Testi 160, Città del Vaticano 1952, 96; Nicolaus Myssticus, Epistula 75, ed. R.H.J. Jenkins - L.G. Westerling: Nicholas I Patriarch of Constantinople [Nicolaus Mysticus], Letters, Dumbarton Oaks Texts 2. CFHB (Series Washingtonensis) 6, Dumbarton Oaks 1973, 327; Romualdus Salernitanus, Chronicon (A.m. 130 - A.c. 1178), ed. C.A. Garufi, Rerum Italicarum Scriptores 7/1, Città di Castello - Bologna 1935, 163; R. Jenkins, The Chronological Accurancy of the „Logothete” for the years a A 867-913, DOP 19 (1965) 104; R.H. Dolley, The Lord High Admiral Eustathios Argyros and the Betrayal of Taormina to the African Arabs in 902, w: Atti del VIII Congresso Internazionale di Studi Bizantini (Palermo, 3-10 April 1951), ed. S.G. Mercati, vol. 1, Studi Bizantini e Neoellenici 7, Roma 1953, 340; T. Wolińska, Sycylia w polityce bizantyńskiej w VI-IX w., Byzantina Lodziensia 8, Łódź 2005, 216-217. Arabowie kilkakrotnie próbowali zdobyć Taorminę, m.in. w 878 (Ibn al-Athir, Cronaca compiuta, s. 396), w 879 (podaję za: А.А. Васильев, Византия и арабы, t. 2: Политические отношения Византии и арабов за время Македонской династии, Санкт-Петербуг 1902, 146-147) i w 881/882 roku (Bizantyńczycy pokonali wówczas wojska arabskie, ale wkrótce potem ponieśli klęskę, por. Ibn al-Athir, Cronaca compiuta, s. 398).

${ }^{11}$ Podstawowym źródłem jest tu świadectwo Jana Kameniaty: Joannes Cameniata, De excidio Thessalonicensi, rec. I. Bekker, CSHB 31, 487-600. Szerzej na ten temat, por. Khoury Odetallah, Leo Tripolites, s. 97-102; Farag, Some Remark, s. 133-139; P. Kazhdan, Some Questions Addressed to the Scholars who Believe in the Authencity of Kamitiates' Capture of Thessalonica, ByZ 71 (1978) 301-317; V. Christides, Once Again Camitiates' Capture of Thessaloniki, ByZ 74 (1981) 7-10; H. Grégoire, Le communiqué arabe sur la prise de Thessalonique (904), „Byzantion” 22 (1953) 373-378; Tougher, The Reign of Leo VI, s. 184-189.

${ }^{12}$ Por. R. Browning, Byzantium and Bulgaria. A Comparative Study across the Early Medieval Frontier, London 1975, 57; Васильев, Византія и Apaбы, t. 2, s. 1 і 127; tenże, Histoire de l'Empire Byzantin, t. 1: (324-1081), trad. P. Brodin - A. Bourguina, Paris 1932, 404-405; A. Vogt, La jeunesse de Léon VI le Sage, RevH 174 (1934) 411. 
żadnego doświadczenia wojskowego ${ }^{13}$, ale to samo można powiedzieć o wielu innych, wśród nich o Justynianie I Wielkim (11 V 483 - 13 XI 565; cesarz od 1 VIII 527). Nie oznacza to, że lekceważył sprawy obronności, na co zwrócili uwagę m.in. Patricia Karlin-Hayter i Shaun Tougher ${ }^{14}$. Z pewnością czynnikiem poważnie ograniczającym jego możliwości działania były problemy wewnętrzne - na przykład spisek Andronika Dukasa (ok. 855 - ok. 910) i Eustacjusza Argyrosa ( $†$ ok. 910) w 901 r., wspierany przez patriarchę Mikołaja Mistyka (852 - 15 V 925; patriarcha Konstantynopola: 901-907 i 912-925) (15 $^{15}$

Mimo wspomnianych trudności wewnętrznych Leon VI podjął próbę reorganizacji wojska bizantyńskiego i podniesienia jego sprawności bojowej ${ }^{16}$. Jedną z jego ważniejszych decyzji była nominacja Himeriosa (floruit: pocz. $\mathrm{X}$ w.) na dowódcę floty (drongariosa $)^{17}$. Jednak działania cesarza nie mogły od razu przynieść radykalnej poprawy. Nie powiodła się próba odbicia Krety $(911)^{18}$ a flota, dowodzona przez Himeriosa została pokonana u północnych wybrzeży Wysp Egejskich ${ }^{19}$. Poniosła też porażkę pod Chios (912). Jedynym sukcesem Bizancjum na morzu było pokonanie floty arabskiej, dowodzonej przez Leona z Trypolisu, na Morzu Egejskim koło Lemnos $(917)^{20}$. Sytuacja cesarstwa była tym trudniejsza, że Arabowie nie byli jedynym, liczącym się przeciwnikiem. Wojska cesarskie poniosły szereg klęsk w wojnach z wdzierającymi się w granice państwa Bułgarami (894-896) i Rusami (911) ${ }^{21}$.

Sytuacja zaczęła się zmieniać na korzyść cesarstwa za rządów Konstantyna Porfirogenety (2 IX 911 - 9 XI 959; cesarz od 6 VI 913) i Romana Lekapena.

${ }^{13}$ Albert Vogt (La jeunesse de Léon VI le Sage, s. 407-408) sądzi, że cesarz otrzymał jakieś podstawy wyszkolenia wojskowego. Innego zdania jest Shoun Tougher (The Reign of Leo VI, s. 167), który wskazuje, że Leon nie był przewidziany na następcę tronu, a gdy nim został po śmierci brata, brakło już czasu na tego rodzaju trening. Jego brak nie musiał być przeszkoda, by podjacć się uczestniczenia w kampaniach. Nie wiadomo dlaczego Leon tego nie czynił. Możliwe, że nie pozwalało mu na to zdrowie, a może po prostu nie miał do takich zajęć upodobania. Wystarczała mu funkcja, jak powiedzielibyśmy dzisiaj, zwierzchnika sił zbrojnych (tamże, s. 168).

${ }^{14}$ Por. P. Karlin-Hayter, ,When military affairs were in Leo's hands”: a note on Byzantine foreign policy (886-912), „Traditio” 23 (1967) 15-40, spec. s. 16, 19-20 i 29; Tougher, The Reign of Leo VI, s. 165-167. Osiagnięcia cesarza podkreślili też Mark Whittow (The Making of Byzantium, 600-1025, Berkeley - Los Angeles 1996, 314-315) i Warren Treadgold (Bizancjum i jego armia 2841081, tłum. A. Grabska-Ryńska, Wodzisław Śląski 2011, 226).

${ }^{15}$ Por. Farag, Some Remarks, s. 137, nota 29.

${ }^{16}$ Por. Tougher, The Reign of Leo VI, s. 193.

${ }^{17}$ Dobrą opinię wystawił mu Niketas (Vita sanctae Theoctistae 2, ed. H. Delehaye - P. Peeters, ASanc Nov. IV, Bruxellis 1925, 225). O jego działaniach przeciw Arabom w latach 909-911 piszą Al-Tabari (839-923) i Al-Masudi (ok. 895-956).

${ }^{18}$ Por. R. Jenkins, The Date of Leo VI’s Cretan Expedition, w: Mélanges Kyriakides, Thessalonike 1953, 277-281.

${ }^{19}$ Por. Khoury Odetallah, Leo Tripolites, s. 98.

${ }^{20}$ Por. Vasiliev, Histoire de l'Empire Byzantin, s. 405.

${ }^{21}$ Por. Tougher, The Reign of Leo VI, s. 173-183. 
Zawarcie pokoju z Bułgarami pozwoliło na skoncentrowanie się na wschodnich granicach. Wybitny dowódca, Jan Kurkuas (prz. 900 - ok. 946) ${ }^{22}$ poprowadził kilka dalekosiężnych rajdów na terytoria arabskie, docierając w $928 \mathrm{r}$. aż pod Dwin i do jeziora Wan ${ }^{23}$. Podjęto też próby zdobycia Meliteny (Malatia), uwieńczone sukcesem w roku $934^{24}$. Zapoczątkowało to serię sukcesów bizantyńskich, którym sprzyjało słabnięcie kalifatu abbasydzkiego ${ }^{25}$. W latach 942-944 Jan Kurkuas prowadził intensywne działania przeciw muzułmanom m.in. w rejonie miast Dary, Amidy, Edessy oraz innych miejscowości leżących za Antytaurusem, biorąc licznych jeńców i łupy ${ }^{26}$. Wprawdzie w $949 \mathrm{r}$. ponownie nie udało się odzyskać Krety, ale cesarstwo odnotowało sukcesy w rejonie $\mathrm{Kaukazu}^{27}$.

Osłabnięcie władzy Abbasydów w Bagdadzie na początku X w. wykorzystali Hamdanidzi z północnego Iraku (Al-Dżazira) i Syrii. Począwszy od lat trzydziestych X w. zaczęli budować swą potęgę, a w końcu następnego dziesięciolecia stali się najpoważniejszym przeciwnikiem Bizancjum ${ }^{28}$. Udało się im stworzyć silną dynastię, która dominowała w regionie w latach 890-1004. Hamdanidzi byli potomkami starego rodu Banu Taghlib - chrześcijańskiego plemienia z Mezopotamii i Wschodniej Arabii. Ich protoplastą był Hamdan ibn Hamdun (floruit: 868-895), zarządca Mardin w południowo-wschodniej Anatolii w czasach Abbasydów (890) ${ }^{29}$. Jego syn, Abd Allah (904-929), został

${ }^{22}$ Jana porównywano z Trajanem (18 IX 53 - 8/9 VIII 117, cesarz od 27/28 I 98) i Belizariuszem (ok. 505-565) (Theophanes Continuatus, rec. I. Bekker, CSHB 31, 427. Również współcześni badacze doceniają jego kompetencje, por. Vasiliev, Histoire de l'Empire Byzantin, s. 405-406.

${ }^{23}$ Por. Whittow, The Making of Byzantium, s. 317; W. Treadgold, A History of the Byzantine State and Society, Stanford 1997, 480. W toku swych kampanii Janowi zdarzało się oddalać o blisko $500 \mathrm{~km}$ od terytorium cesarstwa.

${ }^{24}$ Por. Georgius Monachus, Vitae imperatorum recentiorum, CSHB 31, s. 907-908. Zob. Whittow, The Making of Byzantium, s. 317.

${ }^{25}$ Szerzej na temat działań Bizancjum zob. Whittow, The Making of Byzantium, s. 318-323; J. Hauziński, Burzliwe dzieje kalifatu bagdadzkiego, Warszawa - Kraków, 181-276.

${ }^{26}$ Por. Georgius Monachus, Vitae imperatorum recentiorum, CSHB 31, s. 915; Yahya ibn Sa’ïd Antiochensis, Annales, ed. et trad. français par I. Kratchkovsky - A. Vasiliev: Histoire de Yahya ibn Sa '̈̈d d'Antioche continuateur de Sa'ïd ibn Bitriq, PO 18/5 (pierwsza edycja Paris 1924, wg nowej numeracji = PO 90), Paris 1957, 730 i 733 (cytuję wg wydania z 1957 r.); J.-C. Cheynet, Les Phocas, w: Le traité sur la guérilla (De velitatione bellica) de l'empereur Nicéphore Phocas (963969), texte établi par G. Dagron - H. Mihaescu, traduction et commentaire par G. Dagron, Le Mond Byzantin, Paris 1986, 298-299; Whittow, The Making of Byzantium, s. 321; Treadgold, A History of the Byzantine State and Society, s. 484 (datuje początek ofensywy na 941 r.). Odzyskano m.in. słynny mandylion z Edessy.

${ }^{27}$ Por. Yahya ibn Sa'ïd Antiochensis, Annales, PO 18/5, 768; Theophanes Continuatus, rec. Bekker, s. 428. Zob. Whittow, The Making of Byzantium, s. 322.

${ }^{28}$ Por. Whittow, The Making of Byzantium, s. 320.

${ }^{29}$ Szerzej na temat Hamdanidów zob. M. Canard, Histoire de la dynastie des Hamdanides de Jazîra et de Syrie, Alger 1951. 
mianowany zarządcą Mosulu w północnym Iraku (906), a potem zarządcą Bagdadu (914) ${ }^{30}$.

Z kolei potomkowie tego ostatniego władali Mosulem i Aleppo ${ }^{31}$. Swą potęgę budowali nie zawsze uczciwie. Al-Hasan ibn Abd Allah ibn Hamdan († ok. 969) zamordował, łamiąc świętą zasadę gościnności, przebywającego u niego z wizytą Ibn-Raika (†942), emira emirów (amir al-umara) i kalifa bagdadzkiego ${ }^{32}$. Posiadłości ofiary włączył do swoich dóbr. Równocześnie roztoczył opiekę nad kalifem Al-Muttakim (908-968; kalif: 940-944), ciaggle zagrożonym utratą władzy, za co on i jego brat zostali wynagrodzeni tytułami, pod którymi przeszli do historii jako Nasir ad-Daula (Obrońca Dynastii/

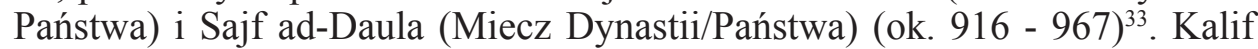
zgodził się też na ślub swego syna z córką Nasira ad-Dauli ${ }^{34}$. W 944 r. Sajf ad-Daula z pomocą brata ruszył na Syrię. W 947 r. zdobył Aleppo, które stało się stolicą państwa niezależnego od Abbasydów.

Ali Sajf ad-Daula rządził (945-967) północną Syrią i był jednym z najgroźniejszych przeciwników Bizancjum ${ }^{35}$. Toczył walki z Bizantyńczykami, którzy próbowali odzyskać swoje wpływy na zajętym przez niego terenie. Walki między Hamdanidami a cesarstwem miały okresowy charakter - nie oznaczały przerwania kontaktów handlowych i kulturowych ${ }^{36}$. Jednak niemal corocznie, czasem nawet 2-3 razy w roku, małe oddziały najeźdźców przekraczały granicę i łupiły terytoria bizantyńskie. Sajf ad-Daula odniósł kilka istotnych zwycięstw nad armią bizantyńską. Wprawdzie w $950 \mathrm{r}$. musiał się wycofać z marszu w kierunku Bosforu, ale w 953 r. rozbił siły Bardasa Fokasa (ok. 878 - ok. 968) koło Germanikei (wódz bizantyński został ranny, zaś jego syn dostał się do niewoli) ${ }^{37}$. Bardas ponownie został pokonany w roku 954 i $955^{38}$.

${ }^{30}$ Por. E. McGeer, The Offspring of Hagar, w: tenże, Sowing the Dragon's Teeth. Byzantine Warfare in the Tenth Century, Dumbarton Oaks Studies 33, Washington 1995, 226.

${ }^{31}$ Hamdanidzki emirat Mosulu Nasira ad-Dauli powstał w 944 r. Po trzyletnich walkach z Ichtyszydami z Egiptu (byli nominalnymi zwierzchnikami Syrii) z kolei Sajf ad-Daula wykroił dla siebie potężny emirat ze stolicą w Aleppo (McGeer, The Offspring of Hagar, s. 226).

32 Por. Hauziński, Burzliwe dzieje kalifatu, s. 269.

${ }^{33}$ Por. McGeer, The Offspring of Hagar, s. 226; G.T. Dennis, Skirmishing. Introduction, w: Three Byzantine Military Treatises, s. 137.

${ }^{34}$ Za rękę córki Hamdanidy wypłacić miał mu kolosalną kwotę 600 tysięcy dirhamów, czym doprowadził do ruiny swój skarbiec. Gdy doszło do buntu nieopłacanych wojsk przeciw kalifowi, jego „opiekun” zamiast walczyć z rebelią wyjechał do Mosulu, por. Hauziński, Burzliwe dzieje kalifatu, s. 270.

${ }^{35}$ Sajf ad-Daula miał duże aspiracje, nie tylko wojskowe. Był poetą, mecenasem nauki i literatury. Jego dwór stał się centrum kultury i rozwoju literatury arabskiej. Zapraszano nań wybitnych przedstawicieli ówczesnej arabskiej nauki i kultury.

${ }^{36}$ Por. Dennis, Skirmishing. Introduction, s. 137.

${ }^{37}$ Por. Cheynet, Les Phocas, s. 298.

${ }^{38}$ Por. Dennis, Skirmishing. Introduction, s. 139. Oczywiście zdarzały się i sukcesy Bizantyń- 
Wówczas na stanowisku domestyka Wschodu zastąpił go syn, Nikefor (ok. 912 - 11 XII 969; cesarz od 16 VIII 963). W ciągu kolejnych kilku lat Nikefor, jego brat Leon (915/920 - po 971), strateg Kapadocji, i Jan Tzimiskes (ok. 925 - 10 I 976; cesarz od 11 XII 969), zmienili bieg wojny na korzystny dla cesarstwa, odnosząc szereg zwycięstw w północnej Syrii. Nikefor walczył potem o Kretę ${ }^{39}$, a po powrocie - ponownie w północnej Syrii, docierając aż po Aleppo, które zdobył w roku $962^{40}$. Sukcesy wojskowe utorowały Nikeforowi Fokasowi drogę do tronu. Zostawszy cesarzem w 963 r. kontynuował działania przeciw Arabom odzyskując Massikę, Adanę i Tars (963-964) ${ }^{41}$. W 969 r. pod władzę cesarstwa powróciła Antiochia ${ }^{42}$.

W toku walk, o których była mowa powyżej, zostały wypracowane zasadnicze zręby strategii i taktyki będących odpowiedzią na zagrożenie arabskie. Sposoby skutecznego prowadzenia działań były równocześnie doskonalone w trakcie walk z Arabami. Efektem zebranych doświadczeń był wysyp traktatów wojskowych. Do najważniejszych powstałych w tym czasie należą dzieła cesarzy: Leona VI i Nikefora II Fokasa oraz Nikefora Uranosa (floruit: 9801010), wyróżniającego się dowódcy wojskowego. Trzeba w tym miejscu zaznaczyć, że pisząc o tekstach cesarzy mamy na myśli dzieła powstałe pod ich patronatem, niekoniecznie autorskie. Nie zamierzam jednak w tym miejscu szczegółowo zajmować się tą kwestią.

Powyżej wspomniałam już o zainteresowaniu Leona VI sprawami obronności. Najlepszym tego wyrazem są spisane przez niego lub na jego polecenie traktaty wojskowe (młodzieńcze Problemata ${ }^{43}$ oraz późniejsze Taktyka i $\mathrm{Na}$ umachika $)^{44}$. O ile pierwszy z wymienionych tekstów jest w przeważającej

czyków - wódz Nikefor Pastilas powrócił z rajdu na terytoria arabskie z licznymi jeńcami (Leo Diaconus, Historia I 4, CSHB 3, 9, 9 - 10, 17).

${ }^{39}$ Leo Diaconus, Historia II 6-8, CSHB 3, s. 24, 9 - 29, 2.

${ }^{40}$ Por. tamże II 7-8, CSHB 3, 25, 11 - 29, 2 (nie wspomniał jednak o zajęciu Aleppo). Zob. Cheynet, Les Phocas, s. 300; Whittow, The Making of Byzantium, s. 326-327; Vasiliev, Histoire de l'Empire Byzantin, s. 407-408.

${ }^{41}$ Por. Leo Diaconus, Historia III 10-11, CSHB 3, 51, 6 - 54, 4; IV 1, CSHB 3, 55, 1 - 57, 3; IV 3-4, CSHB 3, 58, 11 - 61, 11.

${ }^{42}$ Por. G. Schlumberger, Un empereur byzantin au Xe siècle, Nicéphore Phocas, Paris 1923, 598; R.-J. Lilie, Bisanzio. La seconda Roma, trad. di G. Montinari, I Volti della Storia 176, Roma 2005, 223; Vasiliev, Histoire de l'Empire Byzantin, s. 409. Ten ostatni podkreślił, że nigdy wcześniej muzułmanie nie doznali takiego upokorzenia (tamże, s. 409). Wówczas (969) Said ad-Daula, następca Sajfa, nawrócił się na szyizm. W 987 r. odzyskał Aleppo i poddał się pod zależność egipskich Fatymidów. W 1003 r. Fatymidzi pozbawili władzy Hamdanidów w Syrii.

${ }^{43}$ Por. Leo VI Sapiens, Problemata, ed. A. Dain, Nouvelle Collection de Textes et Documents, Limoges - Paris 1935. Zob. A. Dain, Les stratégistes byzantins, „Travaux et Mémoires” 2 (1967) 354.

${ }^{44}$ Por. Leo VI Sapiens, Naumachica, ed. A. Dain, Nouvelle Collection de Textes et Documents, Paris 1943. Naumachica została zapewne napisana jeszcze przed 904 r. Zawarte w niej zalecenia zostały włączone później także do Taktyki, jako jej 19 księga. Warto też przypomnieć, że Leon VI zachęcił Leona Katakalona do napisania dzieła o wyprawach wojennych, por. Constantinus 
mierze zbiorem wypisów ze Strategikonu Maurycjusza (539 - 27 XI 602; cesarz od 14 VIII 582) $)^{45}$, dwa pozostałe mają sporą wartość poznawczą. Powstała na

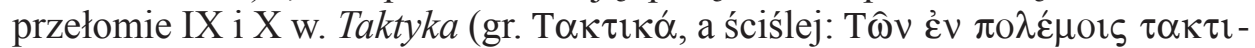

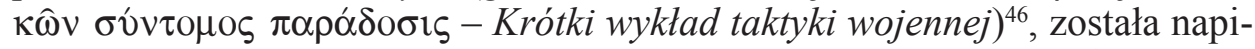
sana na polecenie Leona VI i potem wydana przez Konstantyna VII ${ }^{47}$. Taktyka jest dziełem teoretycznym, napisanym przez osobę nie posiadającą doświadczenia wojskowego, ale nie miała też być w zamyśle dziełem akademickim. Jej cel był czysto utylitarny - miała być podręcznikiem i służyć dowódcom wojskowym $^{48}$. Jej autor wykorzystywał wcześniejsze teksty - Onasandra (I w. po Chr.), Eliana Taktyka (II w. po Chr.) i Strategikon Maurycjusza ${ }^{49}$. Czerpał też z wiedzy swego ojca i dowódców wojskowych ${ }^{50}$. Dzięki temu Taktyka jest jednym z najciekawszych dzieł dotyczących taktyki wojskowej z okresu renesansu macedońskiego. Omówiono w nim zarówno formacje piechoty, jazdy i floty, jak również ich wykorzystanie na polu walki, oblężenia, podstępy

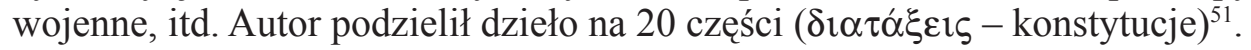

Jednym z zasadniczych powodów spisania Taktyki był wzrost zagrożenia arabskiego. Mimo iż autor traktatu nie miał zapewne doświadczenia wojskowego, jest on cenny dla poznania wojskowości Arabów, bowiem analizie taktyki i organizacji armii muzułmańskiej poświęcono w nim dużo uwagi ${ }^{52}$. Rozważania na ten temat uzupełnione zostały opisem różnorodnych sposobów walki, które powinni stosować dowódcy bizantyńscy w starciach z Saracenami. Charakterystyka wojskowości islamu jest uznawana za najbardziej wartościową część dzieła Leona VI. W Taktyce zebrana została dotychczasowa wiedza Bizantyńczyków o Arabach i ich sposobie wojowania. Dzieło odzwierciedla zatem wyniki świadczeń, zebranych w toku walk, które z muzułmanami toczono od VII w. O tym, że było doceniane przez współczesnych świadczy fakt, iż rozdziały poświęcone walkom z Arabami mają odrębną tradycję rękopiśmienną̨

Porphyrogenitus, Tres tractatus de expeditionibus militaribus imperatoris, ed. J.F. Haldon: Three Treatises on Imperial Military Expeditions, CFHB (Series Vindobonensis) 28, Vienna 1990, 94-97; zob. Tougher, The Reign of Leo VI, s. 168).

${ }^{45}$ Por. G. Dagron, Byzance et le modèle islamique au Xe siècle. A propos des Constitutions tactiques de l'empereur Léon VI, „Comptes Rendus des Séances de l'Académie des Inscriptions et Belles-Lettres” 127 (1983) nr 2, 220, nota 5.

${ }^{46}$ Por. nota 4.

${ }^{47}$ Por. Tougher, The Reign of Leo VI, s. 168-172; Dain, Les stratégistes, s. 354-358.

${ }^{48}$ Por. Karlin-Hayter, ,, When military affairs were in Leo's hands”, s. 21.

${ }^{49}$ Por. Dagron, Byzance et le modèle islamique, s. 220.

${ }^{50}$ Por. A. Thoynbee, Constantine Porphyrogenitus and His World, London 1973, 382.

${ }^{51}$ Niektórzy badacze wnioskują na tej podstawie, że dzieło miało mieć w zamyśle charakter prawodawczy, por. Tougher, The Reign of Leo VI, s. 169; J. Grosdidier de Matons, Trois études sur Léon VI, „Travaux et Mémoires” 5 (1973) 229.

${ }_{52}$ Por. Tougher, The Reign of Leo VI, s. 170; Dagron, Byzance et le modèle islamique, s. 219-243.

${ }^{53}$ Por. Dagron, Byzance et le modèle islamique, s. 220, nota. 9; Tougher, The Reign of Leo VI, s. 171. 
Równie dużą wartość mają traktaty obu Nikeforów. Jak już wspomniano, cesarz Nikefor II Fokas był nie tylko teoretykiem wojskowości, ale także praktykiem. W chwili obejmowania władzy cesarskiej miał za sobą długoletnią służbę $\mathrm{w}$ armii i walki na wschodnim pograniczu. Jest domniemanym autorem traktatu

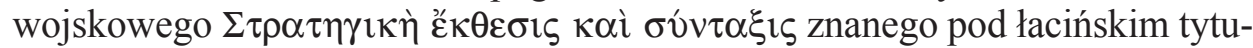
łem Praecepta militaria ${ }^{54}$. Traktat ten został następnie przeredagowany i uzupełniony przez innego wybitnego wodza, Nikefora Uranosa ${ }^{55}$. Autor skoncentrował się w nim na opisie sposobów stawienia czoła wrogiej armii, atakującej terytoria północnej Syrii za górami Taurus. Niewykluczone, że wspomniany wódz napisał również dość obszerny tekst na temat budowy obozu wojskowego i organizacji wypraw wojennych, zazwyczaj przedstawiany jako dzieło anonimowe $^{56}$. Cesarzowi lub komuś z jego otoczenia przypisywane jest też dzieło

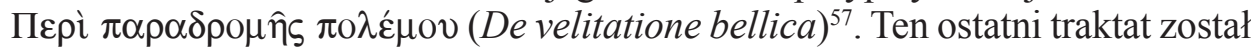
napisany po zwycięstwach nad Arabami (o czym zaświadcza Prolog) ${ }^{58}$, czyli pod koniec lat 60-tych $\mathrm{X}$ wieku ${ }^{59}$. Autorem był zapewne oficer wysokiej rangi, może strateg, osoba, która wcześniej służyła pod dowództwem Bardasa Fokasa. George T. Dennis przypuszcza, że mógł nim być Leon Fokas, brat Nikefora ${ }^{60}$. W obu traktatach znanych pod imieniem Nikefora znajdziemy wskazania, będące wynikiem doświadczeń wynikających z walk z muzułmanami.

${ }^{54}$ Por. Nicephorus II Phocas, Praecepta militaria, ed. E. McGeer: The Praecepta militaria of the Emperor Nicephoros II Phocas, w: McGeer, Sowing the Dragon's Teeth, s. 12-59. Na temat autorstwa traktatu, por. tenże, Nicephoros Phocas and the Praecepta militaria, w: Sowing the Dragon's Teeth, s. 171-174; E.N. Luttwak, La grande strategia dell'Impero Bizantino, trad. di D. Giusti - E. Peru, Milano 2009, 418-434; Dain, Les stratégistes, s. 370-371.

${ }^{55}$ Por. Nicephorus Ouranos, Tactica, ed. E. McGeer: The Tactica of Nikeforos Ouranos, Chapters 56 through 65, w: tenże, Sowing the Dragon's Teeth, s. 88-163. Por. Luttwak, La grande strategia, s. 434-446; Dain, Les stratégistes, s. 371-373.

${ }^{56}$ Traktat ten, znany dawniej pod nazwą De castrametatione, wydał z przekładem angielskim G.T. Dennis: Campaign Organization and Tactics, w: tenże, Three Byzantine Military Treatises, s. 241-335. Edward N. Luttwak (La grande strategia, s. 419) wskazuje na ofensywny charakter działań zalecanych przeciw Hamdanidom. $\mathrm{Z}$ kolei anonimowy traktat De re militari opisuje walki z Bułgarami na Bałkanach, por. Whittow, The Making of Byzantium, s. 187; Luttwak, La grande strategia, s. 409-418.

${ }^{57}$ Tekst znany jest lepiej pod łacińskim tytułem, pod którym opublikowano go po raz pierwszy w roku 1819, por. Whittow, The Making of Byzantium, s. 177; Luttwak, La grande strategia, s. 390-409; Dain, Les stratégistes, s. 369-370. W niniejszym tekście bazuję na edycji G.T. Dennisa, cytowanej w nocie 2. Dostępne jest też wydanie Gilberta Dagrona i Haralambie Mihaescu: Le traité sur la guérilla, s. 29-135.

${ }^{58}$ Por. De velitatione bellica. Prologus, ed. Dennis, s. 146.

${ }^{59}$ Por. McGeer, The Offspring of Hagar, s. 228. Uczony podkreśla, że w traktacie odzwierciedlono doświadczenia wynikające z pierwszego etapu zmagań, gdy cesarstwo odpierało ataki Sajfa ad-Dauli.

${ }^{60}$ Co najmniej, że był inspiratorem napisania dzieła (Dennis, Skirmishing. Introduction, s. 139140). Szerzej na temat autorstwa por. В.В. Кучма, Два трактата - один автор?, „Византийский Временник" 59 (2000) nr 84, 129-144; Dagron, Commentaire, w: Le traité sur la guérilla, s. 171175. Na temat postaci Leona Fokasa zob. Cheynet, Les Phocas, s. 301-306. 
W Taktyce Leona VI Arabowie i ich metody walki zostały omówione W części 18, zawierającej opis formacji bitewnych Rzymian i różnych ludów. Poświęcono im rozdziały 103-135. Na wstępie autor postawił sobie szereg pytań, na które chciał odpowiedzieć - jacy są Saraceni, jaką mają broń i sztukę wojskowa, jak z nimi walczyć ${ }^{61}$. Sporo uwagi poświęcił ich pochodzeniu. Uznał, że Saraceni są etnicznie Arabami ${ }^{62}$ i że początkowo żyli u wejścia do Arabii Szczęśliwej, ale potem opanowali Syrię i Palestynę. Początkowo szukali miejsca do życia (osiedlając się pokojowo?), ale później (dosłownie: po Mahomecie) podbili Syrię, Palestynę, Egipt, Mezopotamię i inne terytoria. Warto zauważyć, że w opinii autora piszacego z perspektywy trzystu lat, sukces zawdzięczali dewastacji tych terytoriów przez Persów ${ }^{63}$.

Oceniając Saracenów stwierdził, że to barbarzyński i pozbawiony wiary $l^{1} d^{64}$. Religię Saracenów określił jako przesąd ( $\left.\delta \varepsilon \imath \sigma ı \delta \alpha \imath \mu o v i ́ \alpha\right)$ Mahometa (ok. 570 - 8 VI 632) ) $^{65}$ i blasfemię ${ }^{66}$. Podkreślał, że nie uznają Chrystusa za Boga. Powtórzył popularny w kręgach chrześcijańskich zarzut, że Saraceni uważają Boga za przyczynę wszystkiego, co złe ${ }^{67}$. Podkreślił też, że w ich przekonaniu Bóg wspiera walczących ${ }^{68}$. Nawiązując do, mającej antyczne korzenie, greckiej nauki o wpływie klimatu na ludzkie charaktery wskazywał, że mają gorący temperament wskutek warunków naturalnych, w których żyją ${ }^{69}$.

W bardzo interesujący sposób Leon przedstawił powody ekspansji arabskiej. Na uwagę zasługuje niemal całkowite pominięcie czynnika religijnego. Cesarz stwierdzał wprost, że najeźdźcy chcą się wzbogacićc ${ }^{70}$ i że większość Saracenów wyrusza na wojnę nie dla sławy, ale by zdobyć łupy, dobra materialne $^{71}$. W ocenie Leona wyruszają do walki nie ze względu na obowiązek i służbę wojskowa, lecz raczej z umiłowania zysku i wolności oraz dla rabunku $^{72}$. Wprawdzie dodał, że walczą także dla wiary ${ }^{73}$, ale zaskakuje, że wymienił ją na końcu. Co więcej, tylko w tym jednym miejscu znajdujemy odniesienie do religii, jako czynnika sprzyjającego agresywnym poczynaniom Arabów. Cesarz wskazywał natomiast sposób ich wychowania i styl życia,

\footnotetext{
${ }^{61}$ Por. Leo VI Sapiens, Tactica XVIII 103.

${ }^{62}$ Por. tamże XVIII 104.

${ }^{63}$ Por. tamże.

${ }^{64}$ Por. tamże XVIII 122. Zarzut barbarzyńskości powtórzył raz jeszcze (tamże XVIII 124).

${ }^{65}$ Por. tamże XVIII 24; XVIII 104.

${ }^{66}$ Por. tamże XVIII 105.

${ }^{67}$ Por. Georgius Monachus, Chronicon IV 235, 8 ed. C. de Boor, vol. 2, Lipsiae 1904, 701

(= PG 110, 869A); Bartholomaeus Edessenus, Elenchus et confutatio Agareni, PG 104, 1393B.

${ }^{68}$ Por. Leo VI Sapiens, Tactica XVIII 105.

${ }^{69}$ Por. tamże XVIII 108.

${ }^{70}$ Por. tamże XVIII 126.

${ }^{71}$ Por. tamże XVIII 130.

${ }^{72}$ Por. tamże XVIII 24.

${ }^{73}$ Por. tamże.
} 
jako powód najazdów. Nie potrafią uprawiać roli i od dziecka są szkoleni, by żyć dzięki mieczowi i umierać od niego - konstatował.

Najważniejsze informacje dotyczyły, co naturalne, wojsk islamskich. Cesarz podkreślał, że Saraceni nie mają armii zawodowej (dosłownie: nie zbierają się wg listy), lecz każdy przybywa z własnej woli wraz z członkami swego domu. Motywy, którymi się kierują, są zróżnicowane w zależności od zamożności: bogaci uważają za wynagrodzenie to, że mogą zginąć za własny naród ( $\varepsilon$ $\theta v o \varsigma)$, biedni pragną bogactw ${ }^{74}$. Arabom łatwo zebrać dużą armię ze względu na ich żądzę łupów i brak lęku przed stratami na wojnie ${ }^{75}$. Miejscami rekrutacji były Syria i Palestyna. Zauważmy, że po raz kolejny Leon podkreślił rabunkowy motyw działań Saracenów. Ciekawe jest natomiast wskazanie na ich solidarność etniczną (nie religijną!).

Leon VI dostrzegł także zaangażowanie całego ludu Saracenów w sprawy wojny. Ich współplemieńcy - zarówno mężczyźni, jak i kobiety - zbyt słabi fizycznie, by nosić broń, zaopatrują w nią wojowników ${ }^{76}$.

Porównując możliwości armii arabskiej i bizantyńskiej cesarz Leon podkreślał przewagę tej ostatniej. „My Rzymianie, przewyższamy barbarzyńców”77 twierdził z dumą, wskazując na liczbę żołnierzy, ich odwagę, wiedzę wojskowă, lepsze wyposażenie w broń i machiny wojenne, jako wyraz tej supremacji. Oczywiście tych słów nie trzeba brać dosłownie, pamiętając, że padają w swego rodzaju podręczniku przeznaczonym dla dowódców armii bizantyńskiej. Tych ostatnich należało natchnąć duchem walki, dodając im wiary we własne siły. Równocześnie jednak cesarz był świadom, że przeciwnika nie wolno lekceważyć. Saraceni stanowili w ocenie Leona poważne zagrożenie i sprawiali równie dużo problemów, jak wcześniej Persowie, każdego dnia czyniąc szkody ${ }^{78}$.

Leon zwracał uwagę na wszechstronność przeciwnika. Pisał, że muzułmanie szkolą swą piechotę do walki na dwu frontach - na lądzie i na morzu. Jeśli nie prowadzą działań wojennych na lądzie (na drogach wiodących do gór Taurus), wsiadają na swe statki, zwane koumbaria i łupią miasta wzdłuż wybrzeża. W każdej chwili jednak, gdy zajdzie potrzeba, gotowi są zaangażować się $\mathrm{w}$ walki na morzu ${ }^{79}$. Są dobrze uzbrojeni - jazda wyposażona jest w łuki, miecze, lance, tarcze i topory ${ }^{80}$. Na wzór rzymski noszą pełną zbroję chroniącą ciało,

\footnotetext{
${ }^{74}$ Por. tamże XVIII 122.

${ }^{75}$ Por. tamże XVIII 126.

${ }^{76}$ Por. tamże XVIII 122.

77 Tamże XVIII 125, CFHB (Series Washingtonensis) 49, 484.

${ }^{78}$ Por. tamże XVIII 135.

${ }^{79}$ Por. tamże XVIII 131.

${ }^{80}$ Por. tamże XVIII 110.
} 
kirysy, hełmy, osłony na golenie, rękawice. Broń zdobią szczodrze srebrem ${ }^{81}$. O skuteczności armii arabskiej w znacznej mierze decydują świetne konie ${ }^{82}$.

Wiele uwagi Bizantyńczyk poświęcił strategii i taktyce arabskiej. Podkreślił, że Saraceni uczą się od Rzymian, naśladują ich ${ }^{83}$. To, czego kiedyś od nich doświadczyli, teraz wykorzystuja przeciwko nim $^{84}$. Na tle innych ludów wyróżniają się tym, że słuchają rad i uczą się metod walki. Leon mógł się w tym przypadku powołać na opinie innych dowódców bizantyńskich - twierdzili tak też poprzedni władcy, m.in. Bazyli. Zaskakiwać może, silnie akcentowane przez cesarza, zdyscyplinowanie oddziałów saraceńskich. Według niego potrafią stosować w walce różne formacje (Leon wspomina czworokątnej, wydłużonej i trwałej, czyli prostokątnej) ${ }^{85}$. Tworzą je w marszu i przygotowując się do bitwy. Czynią tak nie tylko w walkach pieszych, ale też w walkach na morzu, walcząc burta w burtę ${ }^{86}$, czyli techniką abordażu. Ćwiczą też inne modele formacji bitewnych ${ }^{87}$. W ich tworzeniu wykazują się pomysłowością i solidnością.

Ze względu na tę ostatnią cechę formacje Saracenów niełatwo jest rozbić atakiem $^{88}$. Wytrzymują ataki wroga, a gdy zauważą, że jego impet słabnie atakują zaciekle ${ }^{89}$. Nie boją się nagłego ataku i gdy symulują odwrót nie są zbyt rozluźnieni ${ }^{90}$. Pod ostrzałem z łuków, gdy wróg wystrzeli, tworzą ścianę z tarcz, a potem szybko masą ruszają do przodu, by rozpocząć walkę wręcz. W czasie walki używają trąb i cymbałów, by straszyć konie wroga - ich własne są oswojone $\mathrm{z}$ tym hałasem ${ }^{11}$. Z rozmysłem wykorzystują również wielbłądy, których boją się nieoswojone z nimi konie ${ }^{92}$. Przed kawalerią stawiają do walki pieszych żołnierzy, Etiopów, lekko uzbrojonych, wyposażonych w łuki ${ }^{93}$. Warto w tym miejscu zauważyć, że w czasie ataku Leona z Trypolisu na Tesalonikę wśród załóg floty egipskiej byli Etiopowie ${ }^{94}$, w których Vassilios Christides widzi czarnoskórych wojowników z Sudanu, o których źródła arabskie piszą jako o znakomitych żołnierzach, których waleczność jeżyła włosy na głowie ich wrogom ${ }^{95}$. Możliwe, że u Leona VI pod określeniem „Etiopowie”

\footnotetext{
${ }^{81}$ Por. tamże XVIII 111.

${ }^{82}$ Por. tamże XVIII 129. W tej kwestii autorzy bizantyńscy byli zgodni (McGeer, The Offspring of Hagar, s. 239-240).

${ }^{83}$ Por. Leo VI Sapiens, Tactica XVIII 114.

${ }^{84}$ Por. tamże.

${ }^{85}$ Por. tamże XVIII 118.

${ }^{86}$ Por. tamże XVIII 116.

${ }^{87}$ Por. tamże XVIII 114.

${ }^{88}$ Tamże XVIII 113.

${ }^{89}$ Por. tamże XVIII 116.

${ }^{90}$ Por. tamże XVIII 115.

${ }^{91}$ Por. tamże XVIII 106.

${ }^{92}$ Por. tamże XVIII 106; XVIII 134.

${ }^{93}$ Por. tamże XVIII 109.

${ }^{94}$ Por. Joannes Cameniata, De excidio Thessalonicensi 45-49.

${ }^{95}$ Por. Christides, Once Again Camitiates' Capture of Thessaloniki, s. 8.
} 
także kryją się Sudańczycy lub Nubijczycy, bowiem w źródłach bizantyńskich termin ten zwykle dotyczy osób ciemnoskórych.

Sporo uwagi cesarz poświęcił logistyce. Informował, że piechotę wrogowie przewożą na miejsce walki, by zaoszczędzić żołnierzom trudów marszu i zwiększyć tempo przemieszczania oddziałów. Według Leona piesi wojownicy dostawali osobne konie lub, gdy odległość nie była duża, piechur siadał na zwierzęciu za kawalerzystą ${ }^{96}$. Dalej Leon informował, że do transportu bagażu zamiast wozów i jucznych zwierząt (koni?) Saraceni używali wielbłądów, osłów i mułów ${ }^{97}$. Nieobce były im techniki wprowadzania w błąd przeciwnika - wykorzystywali wielbłądy i juczne zwierzęta, by stworzyć wrażenie większej liczebności ${ }^{98}$.

Autor Taktyki podkreślał liczne zalety armii arabskiej w walce. W jego opinii Saraceni są odważni w ataku, gdy spodziewają się zwycięstwa ${ }^{99}$. Nie dają się sprowokować i przygotowani do bitwy nie łamią szeregów, nawet prowokowani ${ }^{100}$, aż do chwili, gdy czują się dostatecznie silni, by zaatakować lub tak słabi, by się wycofać. Nie łamią szyku ani wówczas, gdy ścigają wroga, ani wówczas, gdy są ścigani ${ }^{101}$. Zauważmy, że po raz kolejny cesarz położył nacisk na zdyscyplinowanie oddziałów przeciwnika. To ewidentnie nie byli barbarzyńscy koczownicy. Atakując ich trzeba było być gotowym na wszyst$\mathrm{ko}^{102}$. Za szczególnie groźne cesarz uznał letnie ataki Arabów. W jego opinii rozkwitali w walce przy dobrej pogodzie, w ciepłych okresach. Wtedy łączyli się z mieszkańcami Tarsu w Cylicji i ruszali na kampanie. W innych porach roku tylko niewielkie grupy odważały się na takie rajdy ${ }^{103}$. W tym przypadku cesarz ulegał, jak się wydaje, dość rozpowszechnionym w cesarstwie stereotypom na temat koczowników ${ }^{104}$.

Niezależnie od swych wysokich kwalifikacji bojowych Arabowie mieli też pewne słabości. Zdaniem Leona, chociaż nie łamią łatwo szyku ani wówczas, gdy ścigają wroga, ani wówczas, gdy są ścigani ${ }^{105}$, to jednak gdy już się im to zdarzy, nie są w stanie ponownie się zebrać - myślą tylko o ratowaniu własnej skóry. Jeśli ich nadzieje na zwycięstwo się nie spełnią, stają się tchórzliwi $^{106}$. Ta ocena zapewne daleka jest od obiektywizmu. Jak zauważył przy innej

${ }^{96}$ Por. Leo VI Sapiens, Tactica XVIII 110. Z tekstu Leona wynika, że do transportu piechoty wykorzystywano konie. Nie ma tu mowy o wielbłądach.

${ }^{97}$ Por. tamże XVIII 106.

${ }^{98}$ Por. tamże XVIII 107.

${ }^{99}$ Por. tamże XVIII 112.

${ }^{100}$ Por. tamże XVIII 129.

${ }^{101}$ Por. tamże XVIII 111.

${ }^{102}$ Por. tamże XVIII 116.

${ }^{103}$ Por. tamże XVIII 119.

${ }^{104}$ Por. Dagron, Byzance et le modèle islamique, s. 221.

${ }^{105}$ Por. Leo VI Sapiens, Tactica XVIII 111.

${ }^{106}$ Por. tamże XVIII 112. 
okazji V. Christides, ucieczka przed silniejszym wrogiem to modus vivendi Saracenów ${ }^{107}$. Nie wynika z braku odwagi, lecz jest wynikiem świadomej strategii. Jestem skłonna zgodzić się z jego oceną. Leon VI upatrywał powodów takiego zachowania w religijnych przekonaniach Saracenów. W jego ocenie, gdy doznają porażki od Rzymian uważają, że sam Bóg zwrócił się przeciwko $\operatorname{nim}^{108}$. Z tego powodu przymusowy odwrót przyjmują jako wolę Boga ${ }^{109}$.

Dla bizantyńskich dowódców istotne było jednak to, że wrogowie, odrzuceni gwałtownym atakiem, stają się całkowicie bezradni ${ }^{110}$. Boją się ataku i bitwy w nocy, szczególnie gdy przemierzają obcy kraj ${ }^{111}$. Nie lubią zimna i ciężkich deszczów, między innymi dlatego, że w deszczu cięciwy ich łuków stają się wiotkie i słabe - wtedy należy ich atakować ${ }^{12}$.

Wiele uwagi autor Taktyki poświęcił temu, w jaki sposób należy skutecznie walczyć z muzułmanami. Przede wszystkim należy śledzić ich poczynania przy użyciu szpiegów ${ }^{113}$. Można atakować ich tylko wówczas, gdy dysponuje się dobrze wyposażonymi i zebranymi w całość siłami ${ }^{114}$. Najlepiej czynić to $\mathrm{w}$ czasie, gdy wyruszają na grabież, zwłaszcza w zimie. Trzeba ich atakować w wąskich przejściach górskich Taurusu, gdy wyruszają grabićn ${ }^{115}$ lub gdy wracają wyczerpani i obciążeni łupem. W trakcie ataku należy umieścić łuczników i procarzy w wysokich miejscach, by mogli ostrzeliwać Arabów, zanim nastąpi atak konnicy ${ }^{116}$. Jeśli trzeba, należy stosować staczanie kamieni ze wzgórz, barykadowanie dróg drzewami itp. Ponieważ armia arabska w Cylicji nie jest zbyt liczna (ci sami ludzie walczą na lądzie i na morzu), trzeba atakować ich na ich własnym terytorium w czasie, gdy wyruszyli z niego na grabież. Gdy grasują na morzu, należy uderzać na lądzie, jeśli atakują na lądzie - atakować obszary nadbrzeżne z wykorzystaniem dromonów floty Kybyrraiotai ${ }^{117}$. Zdaniem autora Taktyki, za takim postępowaniem przemawiały doświadczenia poprzedników - gdy Abulfer (Abu Dżafar?) (ok. 712-775; kalif od 754) zaatakował Kapadocję, Nikefor Fokas uderzył na Tars i Cylicję wyrządzając Saracenom duże szkody ${ }^{118}$.

\footnotetext{
${ }^{107}$ Por. V. Christides, Saracens’ Prodosia in Byzantine Sources, „Byzantion” 40 (1970) 12.

${ }^{108}$ Por. Leo VI Sapiens, Tactica XVIII 24.

${ }^{109}$ Por. tamże XVIII 112.

${ }^{110}$ Por. tamże.

${ }^{111}$ Por. tamże XVIII 113.

${ }^{112}$ Por. tamże XVIII 118.

${ }^{113}$ Por. tamże XVIII 132.

${ }^{114}$ Por. tamże XVIII 120.

${ }^{115}$ Por. tamże XVIII 128.

${ }^{116}$ Por. tamże.

${ }^{117}$ Por. tamże XVIII 132.

${ }^{118}$ Por. tamże XVII 65. Na temat imienia wodza muzułmańskiego zob. Cheynet, Les Phocas,
} s. 293-296. 
Jeśli to Saraceni są stroną atakująca, trzeba wytrzymać pierwszy szturm arabskich łuczników ${ }^{119}$. Wyciągając wnioski z tego, jak istotną rolę $\mathrm{w}$ armii arabskiej odgrywała konnica, cesarz zalecał, by atakować i ranić konie przeciwników, np. przy użyciu zatrutych strzał ${ }^{120}$. Podkreślał, że Arabowie chronią swe konie, bowiem pozbawieni ich giną (zatem chroniąc konie, chronią samych siebie). Innym celem ataku winny być słabo opancerzone oddziały Etiopów i łuczników ${ }^{121}$. Należy także oswajać konie bizantyńskie z dźwiękami trąb i cymbałów oraz z wielbłądami, których się boją ${ }^{122}$.

W opinii Shauna Toughera cesarz poprawnie zidentyfikował problemy armii bizantyńskiej, zarówno lądowej jak i sił morskich ${ }^{123}$. Leon miał świadomość, że armii rzymskiej brakuje łuczników, by skutecznie stawić czoła Turkom czy Saracenom, że nie posiada ona dostatecznego wyszkolenia i że brakuje jej żołnierzy ${ }^{124}$. Rozumiał, że konieczne jest posiadanie odpowiednio silnej i odpowiednio przygotowanej do walki z Saracenami floty, o czym świadczy włączenie do Taktyki rozdziału poświęconego siłom morskim. Znamienne jest, że cesarz skarżył się, iż na ten temat nie mógł znaleźć wystarczających informacji i musiał korzystać z doświadczeń swych dowódców floty ${ }^{125}$.

Niektóre z zaleceń cesarza świadczą o chęci przejęcia niektórych elementów arabskiej organizacji i sztuki wojennej. Podkreślał na przykład, że przeciw Arabom trzeba mobilizować wszystkich - trzeba, aby ci, co akurat nie walczą wspierali walczących - modlitwa, darami, zaopatrywaniem żołnierzy we wszystko, co jest im niezbędne ${ }^{126}$. Inne zalecenia bywają dość ogólnikowe. Czytamy na przykład, że nie należy ryzykować decydującej bitwy, nawet jeśli ma się przeważające siły, ponieważ wynik zawsze jest niepewny ${ }^{127}$.

$\mathrm{Na}$ uwagę zasługuje fakt, że mało miejsca w zaleceniach Leona zajmują kwestie religijne. Opinia, że Leon VI przypisywał skuteczność oddziałów muzułmańskich wpływom religii ${ }^{128}$ nie wydaje się w tym kontekście dostatecznie uzasadniona. $Z$ drugiej strony zaledwie $w$ dwu miejscach pojawiły się odwołania do Boga, jako siły wspierającej chrześcijan. W myśl pierwszego z nich silna i dobrze uzbrojona armia rzymska winna, z Bożą pomoca, pokonać Arabów ${ }^{129}$. W myśl drugiego trzeba walczyć w imię Boże, licząc że Bóg będzie

\footnotetext{
${ }^{119}$ Por. Leo VI Sapiens, Tactica XVIII 129.

${ }^{120}$ Por. tamże.

${ }^{121}$ Por. tamże.

${ }^{122}$ Por. tamże XVIII 134.

${ }^{123}$ Por. Tougher, The Reign of Leo VI, s. 171.

${ }^{124}$ Por. Leo VI Sapiens, Tactica XI 13; XVIII 4; XVIII 129; zob. Tougher, The Reign of Leo VI, s. 171.

${ }^{125}$ Por. Leo VI Sapiens, Tactica XIX 1.

${ }^{126}$ Por. tamże XVIII 123. Zob. Dagron, Byzance et le modèle islamique, s. 237-238.

${ }^{127}$ Por. Leo VI Sapiens, Tactica XVIII 121.

${ }^{128}$ Por. Dagron, Byzance et le modèle islamique, s. 221 i 223.

${ }^{129}$ Por. Leo VI Sapiens, Tactica XVIII 124; XVIII 126.
} 
walczył u boku Rzymian ${ }^{130}$. Równocześnie jednak w innym miejscu znalazło się stwierdzenie, że gdy wojska cesarstwa były zaangażowane w walkę z Saracenami Boska Opatrzność zesłała Turków, by walczyli z Bułgarami ${ }^{131}$. Wprawdzie cesarz zalecał armii praktyki religijne i podkreślał konieczność otaczania szacunkiem poległych, ale czynił to poza kontekstem muzułmańskim $^{132}$. Ponadto nie było $w$ tych zaleceniach nic nowego - znajdujemy je już we wcześniejszych strategikonach, np. u Maurycjusza.

Co ciekawe, do informacji autora Taktyki stosunkowo niewiele dodali inni autorzy. Dotyczy to w pierwszym rzędzie tych, którzy mieli duże doświadcze-

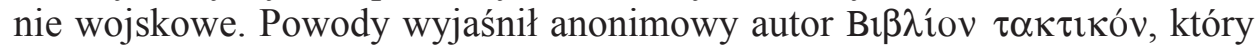
w rozbrajający sposób oświadczył, że dowódcy tak wiele wiedzą o rajdach na ziemie Agarenów, że... nie ma potrzeby omawiać ich szczegółowo ${ }^{133}$.

Analizując tekst De velitatione bellica Gilbert Dagron wyróżnił różne typy najazdów saraceńskich, wspominane przez Nikefora Fokasa, poczynając od pojedynczych ataków grabieżczych, dokonywanych przy użyciu niewielkich grup jeźdźców ${ }^{134}$, przez najazdy połączonych sił jazdy i piechoty, w trakcie których Arabowie zakładali czasowe obozy na zaatakowanych terytoriach ${ }^{135}$, po duże kampanie, $\mathrm{z}$ użyciem znaczących sił ${ }^{136}$.

Z doświadczeń Nikefora Fokasa wynikało, że na te ostatnie wrogowie zbierają zwykle w sierpniu siły z Egiptu, Palestyny, Fenicji, południowej Syrii i Cylicji i we wrześniu, dobrawszy jeszcze do swych sił nieco Arabów, atakują terytoria bizantyńskie ${ }^{137}$. Skuteczną metodą przeciwdziałania temu było, w ocenie Nikefora, najeżdżanie terytorium wroga w czasie gdy i on dokonywał najazdu i był wiele dni marszu od swego obozu. Takie działania podjęto przeciw Alemu synowi Hamdana i pokonano go trzykrotnie, dwa razy za panowania Konstantyna Porfirogenety i raz - za Romana ${ }^{138}$. Dzięki innym źródłom możemy zidentyfikować kampanie, o których mowa. W 950 r. miał miejsce atak arabski na Azję Mniejszą - oddziały wroga dotarły do rzeki Halys. Gdy wycofywały się z łupami i jeńcami wpadły w zasadzkę Leona Fokasa

${ }^{130}$ Por. tamże XVIII 127.

${ }^{131}$ Por. tamże XVIII, 40.

${ }^{132}$ Por. tamże IV, 1; XIII 1; XX 72; tenże, Problemata XII 42. Zob. Dagron, Byzance et le modèle islamique, s. 225-226; J.-R. Vieillefond, Les pratiques religieuses dans l'armée byzantine d'après les traités militaires, REA 37 (1935) 222-230.

${ }^{133}$ Por. Anonymus Byzantinus, De re strategica 32. Na temat autorstwa tego tekstu, por. Кучма, Два трактата, s. 129-144.

${ }^{134}$ Por. De velitatione bellica 6, ed. Dennis, s. 160. Zob. Dagron, Commentaire, s. 178.

${ }^{135}$ Por. De velitatione bellica 8-10, ed. Dennis, s. 164-182. Zob. Dagron, Commentaire, s. 178.

${ }^{136}$ Por. De velitatione bellica 7, ed. Dennis, s. 162-164. Zob. Dagron, Commentaire, s. 179.

${ }^{137}$ Skądinąd wiemy, że ataki mogły następować też w maju i lipcu.

${ }^{138}$ Por. De velitatione bellica 3, ed. Dennis, s. 154-156. 
- Ali ledwie uciekł, tracąc wielu ludzi ${ }^{139}$. W 958 r. Arabowie ponieśli klęskę z rąk Jana Tzimiskesa, zaś w 960 r. pokonał ich Leon Fokas ${ }^{140}$.

Nikefor Fokas uważał za możliwe zablokowanie najeźdźcom możliwości wkraczania do Anatolii, jednak za skuteczniejsze uznawał pozwolenie im na wkraczanie na równinę, gdzie zawsze mogli zostać otoczeni przez przeważające siły bizantyńskie, a odizolowane małe grupy najeźdźców były łatwe do zniszczenia ${ }^{141}$. Zalecał też ewakuowanie ludności cywilnej z zaatakowanych terytoriów ${ }^{142}$. Nikefor zwrócił również uwagę na oddziały Beduinów towarzyszące Hamdanidom i wiele uwagi poświęcił metodom walki z tymi lekkozbrojnymi jeźdźcami ${ }^{143}$.

Jak pamiętamy, również $\mathrm{w}$ opinii anonimowego autora Bißí́ov $\tau \alpha \kappa \tau \imath \kappa o ́ v$, by uchronić się przed atakiem Arabów lub Turków należy wydzielić oddziały łuczników, które będę ochraniać własne jednostki ${ }^{144}$. Należy ponadto zadbać o zaopatrzenie własnych oddziałów. Wkraczając zaś na tereny Agarenów, należy zabrać zaopatrzenie na więcej niż 24 dni, bowiem na spustoszonych terenach trudno zdobyć żywność ${ }^{145}$. Autorzy bizantyńscy nie przypisywali natomiast szczególnego znaczenia zasadzkom, chociaż stosowali je zarówno Rzymianie,

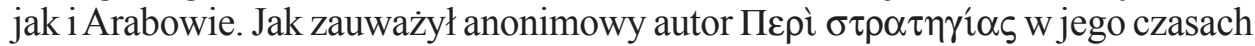
(dosłownie: w chwili obecnej) ich stosowanie nie przynosi wielkich sukcesów ${ }^{146}$.

Autor De velitatione bellica sporą wage przywiązywał do kwestii religijnych. Hamdanidów określał jako wrogów Chrystusa ${ }^{147}$, a żołnierzy walczących w po stronie cesarstwa jako obrońców chrześcijaństwa ${ }^{148}$. Powtarzał za swymi poprzednikami, że to Bóg daje zwycięstwo i że wynagradza walczących. Poszedł jednak dalej, niż jego poprzednicy. Próbował bowiem wprowadzić prawo, czyniące poległych wojowników męczennikami za wiarę, co jednak nie spotkało się z życzliwym przyjęciem w społeczeństwie bizantyńskim ${ }^{149}$.

139 Por. Canard, Histoire de la dynastie des Hamdanides, s. 763-768; tenże, Mutanabbi et la guerre byzantino-arabe. Intérêt historique de ses poesies, w: Al Mutanabbi: Recueil publié à l'occasion de son millénaire, Mémoires de l'Institut Français de Damas, Beyrouth 1936, 99-114.

${ }^{140}$ Por. Leo Diaconus, Historia II 5, CSHB 3, 22, 21 - 24, 8. Zob. Canard, Histoire de la dynastie des Hamdanides, s. 795 i 801-803.

${ }^{141}$ Por. Whittow, The Making of Byzantium, s. 177. Uczony podkreśla, że głównym celem Bizancjum była obrona urodzajnych wybrzeży Azji Mniejszej, a nie centralnej części półwyspu. Zwraca też uwagę, że większość bitew rozegrano na zachodnich rubieżach równiny (tamże, s. 178-179).

${ }^{142}$ Por. tamże, s. 180.

${ }^{143}$ Por. Nicephorus II Phocas, Praecepta militaria II 10, 104-111. Nazywał tych jeźdźców Arabitai. Jak sądzi E. McGeer (The Offspring of Hagar, s. 239) - dla odróżnienia od Agarenoi.

${ }^{144}$ Por. Anonymus Byzantinus, De re strategica 10, ed. Dennis, s. 30-31.

${ }^{145}$ Por. tamże 21, ed. Dennis, s. 72-73.

${ }^{146}$ Por. Por. Anonymus Byzantinus, De re strategica 40, ed. Dennis, s. 118-119.

${ }^{147}$ Por. De velitatione bellica 4, ed. Dennis, s. 156.

${ }^{148}$ Por. tamże 15, ed. Dennis, s. 198; tamże 19, ed. Dennis, s. 214-216. Zob. Dagron, Commentaire, s. 284-286.

${ }^{149}$ Por. Joannes Scylitzes, Synopsis historiarum [Nicephorus II Phokas 18], rec. Thurn, s. 274, 
Przytoczone powyżej opisy metod strategii i taktyki armii muzułmańskich pozwalają stwierdzić, że Bizantyńczycy byli żywotnie zainteresowani poznaniem swych wschodnich przeciwników. Wojskowość arabska przyciagała uwagę zarówno zawodowych wojskowych, jak i osób cywilnych, które - jak cesarz Leon VI - nigdy w życiu nie stanęły na czele żadnej kampanii wojennej. Powód tego zainteresowania był banalny - chciano znaleźć remedium na ataki saraceńskie, przygotować własną armię do stawienia czoła najeźdźcom i wyposażyć jej dowódców w odpowiednią wiedzę o przeciwniku. Stąd też mnogość rozmaitych traktatów wojskowych.

Wyłaniający się z nich obraz sił muzułmańskich jest interesujący, chociaż trudno nazwać go wyczerpującym. Z Taktyki Leona VI czytelnik mógł pozyskać podstawowe informacje na temat uzbrojenia Saracenów, ich wyszkolenia w zakresie tworzenia formacji oraz logistyki. Paradoksalnie, wojskowi zwracali na te zagadnienia mniejszą uwagę, koncentrując się na zaleceniach dla dowódców bizantyńskich. Zapewne wychodzili z założenia, że ci dobrze znają wroga i jego metody walki.

Chociaż „synowie Hagar” byli nie tylko przeciwnikami w znaczeniu polityczno-militarnym, ale też religijnym, w podręcznikach sztuki wojskowej kwestie religijne nie odgrywały pierwszoplanowej roli. Oczywiście żołnierze bizantyńscy modlili się przed bitwą i mieli świadomość, że ich wrogowie nie wierzą w bóstwo Chrystusa. Dowódcy w mowach do podkomendnych odwoływali się do wspólnoty wiary i idei obrony chrześcijaństwa. Nie to jednak decydowało o wyborze taktyki. Nikefor II Fokas był zwolennikiem odwoływania się do uczuć religijnych jako czynnika mobilizującego żołnierzy do walki, a walkę przeciwko muzułmanom uważał za rodzaj misji, co pozwala niektórym badaczom przypisywać mu kierowanie się ideą wojny świętej. Jego kampanie postrzegane sa jako chrześcijańska odpowiedź na ideę dżihadu. Jego postawa nie była jednak powszechna.

Chociaż Arabowie byli śmiertelnymi wrogami cesarstwa autorzy strategikonów rzadko używali wobec nich inwektyw. Co więcej, wydawali się mieć znaczny respekt wobec ich umiejętności. Leon VI, doceniając przeciwników i ich wiedzę wojskowa, nie był wyjątkiem. Arnold Toynbee (14 IV 1889 - 22 X 1975) napisał wręcz, że Arabowie byli postrzegani przez Bizantyńczyków „as being the most formidable of their adversaries" ${ }^{150}$.

62 - 275, 70; Joannes Zonaras, Epitomae historiarum XVI 25, 22, ed. Th. Büttner-Wobst, CSHB 50/3, Bonnae 1897, 506, 10-13. Zob. Dagron, Byzance et le modèle islamique, s. 231.

${ }^{150}$ Toynbee, Constantine Porphyrogenitus and His World, s. 382. Uczony zwrócił uwagę na fakt wymienienia przedstawicieli władców muzułmańskich przed przedstawicielami innych narodów - Bułgarów, Franków i in. (tamże, s. 383). Dowodem na słuszność tej uwagi jest świadectwo Kletorologionu Filoteusza (Philotheus, Cletorologium, ed. J.B. Bury, w: tenże, The Imperial Administrative System in the Ninth Century with the Revised Text of the Kletorologion of Philotheos, The 
THE SONS OF HAGAR. BYZANTINE VIEWS ON THE ARAB ARMY IN MILITARY TREATISES OF $9^{\mathrm{TH}}$ AND $10^{\mathrm{TH}}$ CENTURY

\section{(Summary)}

Arab military expansion was a real challenge to the Byzantine Empire. The defeats sustained in wars with the Arabs, whom the Byzantines called sometimes Hagarenes to refer to Biblical Hagar, forced new method of war waging. That knowledge was taken predominantly directly from battlefield.

The Arab menace increased during the reign of Leo VI the Wise (886-912). Albeit not a soldier himself, he took an attempt to reorganize the Byzantine army and navy. Although it did not bring an immediate effect, the Empire gradually began to initiative. The situation changed for better during the reign of Constantine VII Porphyrogennetos (911-959) and Romanos I Lekapenos (919-959). A peace with the Bulgarians allowed to collect substantial forces on the eastern border of the empire.

The weakening of the Abbasids gave way to the Hamdanid dynasty from northern Iraq and Syria to grow to the most serious Byzantine adversary in mid10th century, particularly during the reign of Sayf al-Dawla (945-967), who recorded some remarkable victories over the Byzantine forces.

In 955 Nikephoros II Phokas took over the post of domesticos of the East. Along with his brother Leo, Strategos of Cappadocia and John Tzimiskes, they were able to change the course of war, winning some battles in northern Syria.

The struggle with the Muslims resulted in a number of military treatises, the most known of which were attributed to emperors Leo VI and Nikephoros II Phokas. Although it is not certain if they were written by them themselves, they were certainly created on their behalf.

Among several treatises of Leo VI, the Tactica seems to be the most interesting. The work divided in 20 chapters was meant as a handbook for military commanders. It discussed the organization of infantry, cavalry and navy, and their use in war, as well as that of sieges, ambushes etc. Much attention was paid to Arab logistics. Remarkably little, if any attention was paid to religious grounds as a reason for expansion. Not too surprisingly, much of the work was dedicated to the methods of efficient struggle against Muslims; the author correctly identified both strong and week sides of the Byzantine army. Some points clearly suggest a desire to take over certain elements of organization and war art from the adversary.

\footnotetext{
British Academy Supplemental Papers 1, London 1911, 155-156). Arnold Toynbee (Constantine Porphyrogenitus and His World, s. 383-393) podkreśla też, że z szacunkiem traktowano w Bizancjum jeńców muzułmańskich. Oceny tej nie zmienia filipika, którą Leon Diakon włożył w usta Nikefora. Wódz miał ją wygłosić do żołnierzy w czasie walk na Krecie. Nawiązując do Hagar i Izmaela miał ich nazwać między innymi potomkami służącej, okrutnikami, kłamcami i diabelskimi bestiami (Leo Diaconus, Historia I 6, CSHB 3, 12, 5-14). Wiele z tych określeń dziejopis zaczerpnął z dzieł autorów antycznych.
} 


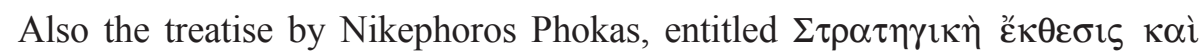
$\sigma \tilde{v} v \tau \xi_{1 \zeta} \zeta$, represents equally good value as Tactica. In this work we find a number of details regarding both military and non-military customs of the Arabs, which is not surprising, as the author was a military commander, experienced in battles against the Muslims. For this reason we should respect even more the military knowledge of Leo's Tactica, if we remember that the author was not a professional soldier. Interestingly enough, with the notable exception of Nikephoros Phokas, the authors of other treatises added little to the information contained in Leo's work. The reason for that was explicitly laid out by an anonymous author of still another

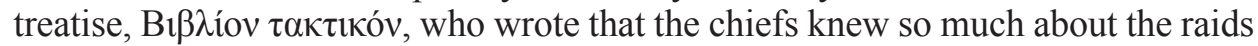
on the lands of the Hagarenes that there was no use to discuss them in detail.

Key words: Byzantium, Arabs, art of war (polemology), military treatises (tactica), Nicephor II Phocas, Leo VI the Wise.

Slowa kluczowe: Bizancjum, Arabowie, sztuka wojenna, taktikon, Nikefor II Fokas, Leon VI Filozof. 